[Article accepted for publication in Marine Policy]

\title{
Trade Politics and the Global Production of Canned Tuna
}

\author{
Dr Liam Campling \\ Senior Lecturer in Political Economy \\ School of Business and Management \\ Queen Mary University of London \\ l.campling@qmul.ac.uk
}

\begin{abstract}
Using the case of canned tuna, this article shows that EU and US tariff regimes profoundly influence the location of processing activities, thereby shaping the international division of labour. It argues that the impact of trade preferences and tariff liberalization cannot be adequately understood without taking into consideration the particular characteristics and circumstances of individual countries. One-size-fits-all policy prescriptions based on generalized assumptions about the functioning of the world economy cannot provide an adequate development policy framework.
\end{abstract}

Key words: Trade policy, development, European Union, United States, tuna, Africa

\section{Highlights}

- Undertakes a critical analysis of approaches to fisheries trade policy and development and argues for greater attention to historical contingency and socio-ecological change.

- Compares EU and US tuna tariff regimes and explains policy formation as based upon domestic-societal interests.

- Demonstrates how the geography of global canned tuna production and its developmental effects are shaped intimately by EU and US trade policy. 


\section{INTRODUCTION}

Despite the existence of a vast literature on fishing industries around the world, very little is known about the effects of fish trade policy on socio-economic development (Béné et al. 2010; Béné et al. 2016). However, a general study of 'fish' tariffs would obscure as much as it might reveal because, as Roheim (2004) points out, species and product differentiation are crucial. This article examines the role of trade policy in shaping the geography of global canned tuna production. It does so in three main steps. The first reviews major theoretical perspectives on the relationship between trade policy and fisheries development. It argues that the ideological polarization of this debate detracts from the importance of historical contingency and social specificity to an understanding of the relationship. The second examines the political economy of canned tuna tariff policy regimes in the European Union (EU) and United States (US). The third step traces the effects of EU and US tuna tariff regimes on the international division of labour and the development of countries in the global South. It concludes by arguing that prescriptions based on simplistic assumptions of the functioning of the world economy do not suffice as a trade policy framework. Industry disaggregation and political-economic context are necessary evidence-bases for fisheries trade policy makers to take account of species- and country-specific dynamics.

\section{TARIFF POLICY AND FISHERIES DEVELOPMENT: PERSPECTIVES}

\subsection{Orthodox liberalisers}

The standard argument for the liberalisation of barriers to trade and investment in fisheries (as with other sectors) is that 'the most cost effective producers with a comparative advantage [should] undertake the operation' (Schmidt 2003: 7; see also Heydon 2006). Following this logic, rather than see fish populations as a national resource to be extracted by national firms, governments should resist resource nationalism and open extraction to international competition. In many cases, the logic of this argument is extended to claim that the only assumed comparative advantage is the generation of rents from fishing licenses; any other interventions adopted by states will only stall or pervert growth, such as industrial policies requiring foreign companies to invest locally to qualify for fishing licenses (Duncan 2006; Peterson 2006). 
The OECD claims that ' $[\mathrm{r}]$ educing tariff escalation will generate further opportunities for developing countries through their participation in international trade of value-added fish products' and that ' $[\mathrm{t}]$ he liberalisation of tariffs and reductions in peaks and escalation [will] ensure fair access to markets for processed products' (2010: 68; for similar statements, see WTO 1997; ICTSD 2006; Martini and Lindberg 2013). The assertion that the liberalisation of tariffs alone will allow 'fair' access can be problematised in light of the layers of other barriers to developing country market access, including the multitude of fisheries subsidies and nontariff barriers applied by OECD governments and the buying power and private standards of branded firms and big retail. As tariffs (and thus tariff preferences) fall in major markets, nontariff measures - particularly public and private food standards - are likely to become the main barriers to market access for fish products, especially for smaller firms and fiscally squeezed states that are less able to spread the costs of investment required to comply with such measures. For example, as Mwikya (2006: 150) points out, the proliferation of standards 'increase the cost of doing business, which in turn necessitates increased catches, hence encouraging disregard for stock conversation measures'.

\subsection{Augmented liberalisers}

In an important departure from the norm, the OECD (2003) qualifies the benefits of fish trade liberalisation. It emphasises that the liberalisation of fisheries markets could deepen unsustainable resource extraction where management is ineffective and in areas where open access is prevalent such as the high seas. Similarly, Roheim (2004: 76) makes plain that fisheries management is 'a necessary condition' and 'the most important factor in the outcome of liberalization of trade' because where stocks are not well managed, 'liberalization will encourage faster depletion of the stocks'.

This qualified support for liberalisation stems from production systems for fish being highly heterogeneous and subject to extensive levels of management, at least compared to other food products (Schmidt 2003). As such, the maximisation of welfare heralded by supporters of tariff liberalisation must be mitigated by attention to the sustainable use of fisheries which depends, among other things, on the state of the resource and of the ability of those charged with managing the extent and intensity of extraction (or barring it altogether) to do so effectively. In his major study of the effects of fish trade on low income food-deficit countries, John Kurien put the point well: 'discussions about sustainable trade attain meaning only in the context of commitments to sustainable production and sustainable consumption' (2005: 59). 


\subsection{Developmentalists}

The 'developmentalist' argument is that state interventions in the market can positively contribute to the prospects of economic development. They tend to take a historical view of the dynamics of capitalist development and highlight the centrality of tariffs and other forms of protectionism to the industrialisation of Western Europe, the United States and parts of East Asia, arguing that 'policy space' is necessary for developing countries to diversify and industrialise their economies (e.g. Chang 2004; Wade 1990). The advantages gained from strategic trade policy can be explained, in part, by increasing returns to scale, which provide a competitive basis for the international trade of most mass manufactures (e.g. Krugman 1983). Moreover, the theoretical validity of comparative advantage is under ever greater question both in relation to the ever-increasing complexity of global value chains in capitalist development (e.g. Milberg and Winkler, 2013) and in the context of high cost structures in small developing economies when comparative advantage 'is not enough' to support local development (Winters and Martins, 2004). On the latter point, in relation to fisheries 'where property rights over a resource stock are hard to define, difficult to enforce, or costly to administer', Brander and Taylor (1997: 527) found that 'trade may be welfare reducing for a small open economy'. Developmentalists often support trade preferences - i.e. reduced import tariffs - to support developing country industries. But to have a minimal chance of working the preference must be commercially significant (Davenport et al. 1995; Manchin 2006) and rules of origin (RoO) must not be overly restrictive (see below).

What do we know about the relationship between tariff policy and fisheries development? On the one hand, there is considerable empirical evidence that without trade preferences and industrial policy economies dependent upon fish processing would become non-competitive in international markets (e.g. Campling and Havice, 2007; Ponte et al., 2007; Campling, 2008). On the other hand, the claims of orthodox liberalisers are challenged by evidence that investment liberalisation did not result in fisheries development or beneficial trade effects (Clark 2006; UNEP 2002a); instead there is some evidence that liberalisation can have negative implications for local socio-ecological development (Allain 2007; Asche and Smith 2010; Brander and Taylor 1997; Nieto 2006; UNEP 2002b).

\subsection{Historical contingency and socio-ecological change}

Béné et al. (2010) review the evidence for the benefits and costs of fish trade liberalisation in Africa. They find the debate to be highly polarised and with little nuance - as typified by the 
three perspectives outlined above. They are particularly scathing of the use of insufficiently disaggregated data sets to make generalised claims. As an alternative, Béné et al. (2010) argue that analyses of international fish trade and development must engage with local specificities and deploy research methods that are suitable to capture both the local and national level dimensions of the problem. Havice and Campling (2013) emphasise the articulations of the specificity of place, environmental conditions of production and relative state capacity in making full use of trade preferences for fish products; and that - on first sight - the hidden costs of maintaining investment in a factory (e.g. direct and indirect subsidies) may put into question 'development' gains (see Section 3). Campling (2015a) suggests that the relationship between trade and fisheries development cannot be read off simply from the technicist perspectives of tariff policy, but that trade policy formation needs to be understood historically. For example, the very existence of the African, Caribbean and Pacific (ACP) group's canned tuna preference (see below) was in the first instance a product of French industrial capital investing in colonial Senegal under the post-War French Union. Combined, these arguments call for sensitivity to social complexity and contingency in the dynamics of change.

\section{TUNA TARIFF POLICY IN THE EUROPEAN UNION AND UNITED STATES}

The international trade in fish continues to be heavily skewed toward the EU, USA and Japan (the global 'Triad'). They totalled $64 \%$ of the value of world seafood trade in 2012, with the EU at 36\% (including intra-EU trade) and Japan and the USA at 14\% each (FAO 2014: 50). Despite the emergence of a new 'middle class' (especially in parts of East and Southeast Asia), the minority global population in the Triad dominate consumption of internationally traded fish.

Aggregate most-favoured-nation (MFN) tariff averages indicate that the world fish trade is liberal compared to agriculture but less liberal compared to manufactured goods (Melchior 2006). There has been little harmonised liberalisation in fish tariffs since the conclusion of the Uruguay Round in 1994, which cut the developed country average from $6.1 \%$ to $4.5 \%$ (OECD 2003). However, applied MFN tariff averages mask both very high peaks for certain fish products and the importance of 'actually applied' tariffs (e.g. preferences and FTAs). This section focuses on the fish tariff regimes of the EU and the US. This is because Japan's average tariff peaks on processed fish are relatively low at 9\% (Ahmed 2006) and its preference system is less significant in the structuring of global tuna production and trade 
(Allain 2007; Campling et al. 2007). The EU and US, in contrast, apply average tariffs on processed fish of $16 \%$ and $20 \%$ respectively (Ahmed 2006).

Tariff escalation seeks to protect domestic processors with high tariff peaks on finished product, while keeping raw material import prices low. While fish tariff escalation is not used only by the OECD countries (Melchior 2006), it has historically been a major tool in the protection of fish processing industries in the EU and US. For example, Table 1 details import tariffs for the EU and the US by HS code for unprocessed, semi-processed and final product tuna for a range of preferential and free trade agreements. The data show a clear tariff escalation policy: MFN treatment is duty free for all imported whole tuna for both jurisdictions, but moves to tariff peaks on canned tuna of $24 \%$ for the EU and $35 \%$ for the US. The importance of trade preferences will be discussed below, but is readily apparent from Table 1. It shows duty free treatment offered to several categories of developing countries, including:

- various incarnations of the Generalised System of Preferences (GSP). For example, the EU GSP regime consists of three pillars: (a) the 'standard' GSP scheme, which excludes only a handful of developing countries; (b) the Everything But Arms initiative (EBA) which provides quota-free, duty-free treatment for all goods (bar arms and munitions) from all countries categorised as LDCs; and (c) the GSP+ which is available to countries that are categorised by the EU as economically 'vulnerable' and have ratified a set of 27 international conventions on labour and human rights and on environmental and good governance.

- the 77 countries of the ACP, established under the ACP-EU Lomé Conventions (19761999) and Cotonou Agreement (2000-20), many of which signed interim or comprehensive Economic Partnership Agreements (EPAs) in 2007 (see Campling 2008b; Campling 2015a).

- the US African Growth and Opportunity Act (AGOA).

Table 1 also details US tariff treatment under several bilateral free trade agreements (FTAs), selected because they are commercially significant exporters of fish products. Where US FTA tariffs are not already zero, many will be entirely phased out over time (see below). 
Table 1: Simplified EU and US tariff schedules for tuna and tuna products (in \% ad valorem unless otherwise specified)

\begin{tabular}{|c|c|c|c|c|c|c|c|c|}
\hline & \multicolumn{4}{|c|}{ European Union } & \multicolumn{4}{|c|}{ United States } \\
\hline $\begin{array}{l}\text { Product/ } \\
\text { HS Code }\end{array}$ & MFN & GSP & $\begin{array}{l}\text { EBA and } \\
\text { GSP+ }\end{array}$ & $\begin{array}{l}\text { ACP/ } \\
\text { EPA }\end{array}$ & MFN & GSP & $\begin{array}{l}\text { LDC GSP } \\
\text { and AGOA }\end{array}$ & FTAs* \\
\hline $\begin{array}{l}\text { Fresh-chilled or } \\
\text { frozen whole tuna/ } \\
0302 / 03\end{array}$ & $\begin{array}{l}0 \text { (under } \\
1604 \text { ) } \\
22 \text { (other } \\
\text { uses) }\end{array}$ & $\begin{array}{c}0 \text { (under } \\
1604 \text { ) } \\
18.5 \text { (other } \\
\text { uses) }\end{array}$ & 0 & 0 & 0 & 0 & 0 & 0 \\
\hline $\begin{array}{l}\text { Prepared or } \\
\text { preserved tuna (in } \\
\text { oil)/ } 1604\end{array}$ & 24 & 20.5 & 0 & 0 & 35 & 35 & 0 & $\begin{array}{c}\text { All: } 0 \\
\text { Except: Peru 14; } \\
\text { Colombia 24.5; Korea } 29\end{array}$ \\
\hline $\begin{array}{l}\text { Prepared or } \\
\text { preserved tuna (not } \\
\text { in oil)/1604 }\end{array}$ & 24 & 20.5 & 0 & 0 & $\begin{array}{l}6 \text { to } \\
12.5\end{array}$ & $\begin{array}{l}6 \text { to } \\
12.5\end{array}$ & 0 & $\begin{array}{c}\text { All: } 0 \\
\text { Except: Central America } \\
0.1 \text { to } 0.4 \text {; Peru } 2.4 \text { to } 5 \text {; } \\
\text { Colombia } 4.2 \text { to } 8.7 ; \\
\text { Korea } 4.9 \text { to } 10.3\end{array}$ \\
\hline $\begin{array}{l}\text { Tuna Loins for use } \\
\text { under 1604/ } 1604\end{array}$ & 24 & 20.5 & 0 & 0 & 6 & 6 & 0 & $\begin{array}{c}\text { All: } 0 \\
\text { Except: Korea } 4.2\end{array}$ \\
\hline
\end{tabular}

* Tariff treatment in 2014 (USTIC 2014a). Notes: The table uses MFN applied tariff rates, but several countries have now replaced this term (e.g. 'Normal Trade Relations' for the US).

** US duties for canned tuna in water depend on a quota that limits imports from any single country to no more than $4.8 \%$ of the total tuna in air tight containers consumed in the previous year. The tariff rate for canned tuna 'not in oil' (e.g., in brine or spring water) shifts from 6 to $12.5 \%$ when the tariff quota is full (USITC 2014 ).

Sources: Adapted from Campling et al. (2007) and updated with USITC (2014). 
Before moving to a focused discussion of the political economy of the absolute tariff levels in Table 1, it is worth emphasizing the potential importance of effective protection resulting from non-tariff barriers and/ or the structure of trade itself. ${ }^{1}$ For example, an import tariff might be zero for frozen whole tuna to be processed by the canning industry and high for loins, but if processors choose to not import whole fish (e.g. because of high labour costs), the structure of trade is such that it provides effective protection to processed imports (Guillotreau and Péridy 2000). This is not the case for the canned tuna industry, but it does suggest a diversity of possibilities for effective protection afforded by tariff policy.

\subsection{The political economy of EU tuna tariff peaks and escalation}

Perhaps the most politically prominent example of tariff escalation and preferences in the EU is for canned tuna (Table 1). The $24 \%$ tariff peak on canned tuna was designed historically by France to protect its processors and was transcribed into EU policy to protect processors in Italy and Spain too. Table 2 combines intra- and extra-EU sources of supply of canned tuna in order to show the major beneficiaries of the tariff regime both within and outside of the EU. In the 2000s Spain was the major supplier to EU markets, closely followed by Ecuador (where the tuna industry is penetrated by considerable Spanish investment). While Italy, France and Portugal are relatively smaller processors, they remain significant. The domestic-societal interests and concomitant political power of canning firms and tuna boat owners (see below) is a major factor in explaining the high tariff (Campling 2015). A parallel policy of tariff escalation keeps raw material input costs low for EU-based processors and provides them with maximum flexibility for sourcing inputs at the lowest price on international markets. Importantly, processors based in preference receiving countries such as the ACP and GSP+ do not benefit from this flexibility because the rules of origin require that they can only process fish caught by vessels owned by firms based in their country or region or the EU. This indicates that the major beneficiaries of EU preference schemes today are the owners of the Europeanowned distant water fleet (DWF). This fleet has a captive market among those ACP and GSP+ producers who do not have a domestic fleet (Campling 2008a). (See below on the effects of this tariff policy on production structures.) Of course, trade policy cannot alone explain the geography of global canned tuna production. The international division of labour is also shaped, among other factors, by access to fish, geo-politics (e.g. historical spheres of influence

\footnotetext{
${ }^{1}$ Thanks to an anonymous peer reviewer for emphasising this point.
} 
of 'national' fleets), the law of the sea (especially UNCLOS), and the relationship between domestic political economy, labour regimes and international investment.

Table 2: Intra and Extra EU sources of canned tuna by major supplying country, in $1,000 \mathrm{mt}$

\begin{tabular}{|c|c|c|c|c|c|c|}
\hline & $\begin{array}{l}\text { Tariff regime (and \% } \\
\text { treatment) }\end{array}$ & 2009 & 2010 & 2011 & 2012 & 2013 \\
\hline Spain & EU $(0 \%)$ & 74.6 & 102.8 & 97.2 & 86.1 & 86.4 \\
\hline Ecuador & $\mathrm{GSP}+(0 \%)$ & 63.7 & 62.2 & 71.5 & 73.7 & 84.1 \\
\hline Thailand & GSP $(21.5 \%)$ & 64.4 & 68.9 & 76.2 & 47.4 & 61.4 \\
\hline Seychelles & EPA $(0 \%)$ & 42.3 & 41.0 & 43.5 & 43.7 & 51.4 \\
\hline Mauritius & EPA $(0 \%)$ & 35.4 & 44.2 & 43.9 & 46.9 & 50.5 \\
\hline Côte d'Ivoire & EPA $(0 \%)$ & 31.5 & 26.3 & 25.7 & 34.6 & 33.5 \\
\hline Philippines & GSP $(24 \%)$ & 54.1 & 45.5 & 35.7 & 31.1 & 29.9 \\
\hline Ghana & EPA $(0 \%)$ & 26.5 & 27.4 & 25.9 & 26.1 & 21.4 \\
\hline PNG & EPA $(0 \%)$ & 14.6 & 15.9 & 15.6 & 19.6 & 18.8 \\
\hline Indonesia & GSP $(21.5 \%)$ & 11.3 & 9.2 & 13.4 & 14.6 & 14.0 \\
\hline Vietnam & GSP $(21.5 \%)$ & 7.8 & 7.3 & 8.5 & 9.4 & 13.2 \\
\hline Italy & EU $(0 \%)$ & 13.3 & 13.8 & 13.9 & 13.0 & 11.6 \\
\hline Colombia & $\mathrm{GSP}+(0 \%)$ & 12.7 & 11.4 & 13.3 & 12.2 & 11.5 \\
\hline France & EU $(0 \%)$ & 12.2 & 6.4 & 5.9 & 6.5 & 7.8 \\
\hline Madagascar & EPA $(0 \%)$ & 7.3 & 6.8 & 9.7 & 8.0 & 7.7 \\
\hline El Salvador & $\mathrm{GSP}+(0 \%)$ & 2.2 & 2.8 & 3.1 & 3.1 & 3.7 \\
\hline Portugal & EU $(0 \%)$ & 2.3 & 2.4 & 3.9 & 3.5 & 3.7 \\
\hline Senegal & $\mathrm{EBA}(0 \%)$ & 1.7 & 0.8 & 0.5 & 0.1 & 1.7 \\
\hline Others & Misc. & 51.2 & 50.5 & 56.6 & 54.6 & 61.3 \\
\hline Total & & 529.2 & 545.7 & 564.0 & 534.5 & $\mathbf{5 7 3 . 5}$ \\
\hline
\end{tabular}

Source: Globefish 2014

To save on labour costs, EU industry also imports pre-cooked, frozen loins for inserting into cans. These are largely imported from developing country suppliers where labour is relatively less costly - what I call a 'logic of loining'. Many of these suppliers benefit from duty free access (e.g. GSP+), but they are unable to meet EU demand. As a result the EU applies 
autonomous tariff quotas which are non-discriminatory partial or full exemptions from import duties on a limited quantity of goods, with the aim of providing EU industry with raw materials should EU-based suppliers not be able to keep pace with demand (Paredes 2006). For example, the EU Single Duty Loins Quota (introduced in 2004) allows for a set quantity of pre-cooked tuna loins to enter the EU duty free from third countries on a 'first-come, first-served' basis (in 2014 the quota was $22,000 \mathrm{mt}$ ). Typically, the quota is fully utilised by the end of the first quarter, although in 2014 the quota was exhausted just ten days after opening - likely taken up mostly by Thai processors who are otherwise subject to pay $24 \%$ duty on loins (Campling and Havice 2014b). This quota is a clear example of an ad hoc policy of tariff escalation in action. It has negative trade diversionary consequences for preference-dependent economies such as the ACP and GSP+ countries vis-à-vis cost competitive processors in Southeast Asia. The quota also illustrates the political power of the EU-based processing firms to successfully lobby the EU and alter trade policy when competitive conditions change (i.e. lower cost intermediate goods are available from third country suppliers). Additionally, in this case, that the quota is volume limited and temporary is an expression of an intra-class compromise between the capitalist interests of EU-based canning firms and the EU DWF, where the latter would prefer to avoid any erosion of the preferential tariff system because rules of origin substantially privilege the fish they catch within the EU-centred supply chain (i.e. by excluding competing fleets).

To be able to utilise EU trade preferences, the beneficiary must comply with strict rules of origin. EU rules of origin for fish are based upon 'wholly obtained' criteria. Under (Interim) EPAs and the EU's current GSP regime, the wholly obtained criteria for fish and fish products are that:

- All fish is automatically wholly obtained when caught inland and within the territorial seas (12 miles from the coast) of the signatories. The location determines origination. This can also include fish caught in a country's archipelagic waters where the proper international legal procedures have been followed through the United Nations. ${ }^{2}$

- If caught outside of these locations, origination is determined by the 'nationality' of the boat (i.e. when caught in exclusive economic zones and in the high seas). Nationality

\footnotetext{
${ }^{2}$ For example, Papua New Guinea obtained a redefinition of its 'territorial sea' to incorporate the sea surrounding its entire archipelago. To receive this status under UNCLOS (1982) Part IV, Articles 47-50, a country declares the waters sovereign and submits the claim to the Division of Oceans and Law of the Sea at the UN (a collection house for declarations). If there is no dispute, the declaration becomes law. Before PNG's application, no other state had made use of archipelagic waters in relation to EU RoO.
} 
is determined by: a) the boat being flagged and registered by one of the parties to the agreement; and, b) being at least $50 \%$ owned either by nationals of parties to the agreement or by a company based in one of the parties to the agreement.

The 'wholly obtained' approach is the basis of all EU preferential rules of origin for fishery products in international preferential trade arrangements, including in the Cotonou Partnership Agreement (and the Lomé Conventions before it). The EU DWF maintains that the RoO contributes to off-setting its higher cost structure compared to less heavily regulated competitors, especially in the realm of 'social and environmental conditions' (FITAG-Anfaco 2011: 2; Estudios Biologicos 2006). From the perspective of preference-receiving trading partners, such as the ACP group, EU fisheries rules of origin have long been perceived as a source of contention due to their restrictiveness (Commission for Africa 2005; Davenport et al. 1995; Grilli 1993; Naumann 2010; Ravenhill 1985).

\section{2}

\section{The political economy of US tuna tariff peaks and escalation}

US tariffs on canned tuna are complex and are a historical legacy of formerly vibrant tuna canning industry on the Californian coast (Felando and Medina 2012). Without tariff protection the two remaining canneries based in the mainland US are highly unlikely to be able to compete with the costs of production in Southeast Asia. Thailand is the clear leader in the US market in volume of canned and pouched tuna product: in 2013 it supplied 53\% of all US imports, followed by Vietnam (12\%), Philippines (11\%), Ecuador (10\%) and China (6\%) (NMFS 2014).

US duty for canned tuna in water ('not in oil' in Table 1) shifts from $6 \%$ to $12.5 \%$ when the tariff quota is full. The quota at $6 \%$ is filled extraordinarily quickly. Table 3 details imported weight of canned tuna in oil and not in oil between 2010 and 2013. The import quota on canned tuna not in oil was set at just over $15,000 \mathrm{mt}$ in 2013 . The volume over quota and thus charged a tariff of $12.5 \%$ was almost 200,000mt in 2013 (NMFS 2014). Several Southeast Asian and Latin American producers report that taking advantage of the quota is both costly and risky as product must be stored in bonded warehouses in the US in advance and there is no guarantee that it will qualify for the quota (Campling et al. 2007; Havice et al. 2014). Canned tuna in oil has a very high tariff at $35 \%$ and offers a potentially very significant advantage for countries benefitting from preferential trade. The US tariff schedule for canned tuna is structured with a high duty on tuna in oil and a lower duty on tuna in water simply because "no one thought that 
anyone would ever be interested in buying tuna in water!' (US Industry representative interview in 2006, cited in Campling et al. 2007: 2). The rise in health consciousness in the US from the 1980s onwards spurred the increase in consumption of tuna in water rather than in oil. Today, canned tuna in oil is a small market segment: at between 3\% and $4.5 \%$ of the canned tuna import market by volume in 2010-13 (Table 3). Tuna loins for reprocessing under 1604 (i.e. to be defrosted and inserted into shelf-stable containers such as cans) are met with a $6 \%$ tariff (when in bags of $6.8 \mathrm{~kg}$ of less or $1.1 \varnothing$ per kilogram when packed in bags of a higher volume). The US market for loins may only exist as long as US trade policy continues to protect domestic canners.

Table 3: US imports of canned tuna in oil and not in oil, in $1,000 \mathrm{mt}^{3}$

\begin{tabular}{|l|c|c|c|c|} 
& $\mathbf{2 0 1 0}$ & $\mathbf{2 0 1 1}$ & $\mathbf{2 0 1 2}$ & $\mathbf{2 0 1 3}$ \\
\hline Albacore in oil & $\mathrm{NS}$ & 604 & 536 & 489 \\
\hline 'Other' canned in oil & 6,068 & 5,800 & 6,889 & 6,281 \\
\hline $\begin{array}{l}\text { Albacore not in oil } \\
\text { 'Other' canned not in } \\
\text { oil }\end{array}$ & 27,611 & 25,554 & 21,964 & 20,632 \\
\hline Total & 166,974 & 155,375 & 131,068 & 131,009 \\
\hline
\end{tabular}

NS = not specified

Source: NOAA Fisheries 2012 and 2014

The US GSP provided for duty free access to developing country beneficiaries for most manufactured items with the exception, among others, of canned tuna where the MFN rate is applied (see Table 1). This anomaly is a direct representation of the political power of the US tuna lobby (e.g. Campling et al. 2007) An extended GSP scheme for LDC beneficiaries includes canned tuna in oil, in water, tuna loins, canned sardines and fish sticks (USTR 2012). However, the US GSP was not renewed by the US Congress when it expired on 31 July 2013 (Jones 2014). While supported by the Obama administration, it is not known if the Republican dominated Congress will re-extend the GSP scheme. In short, given that the GSP is unilaterally granted, it can also be unilaterally withdrawn.

The US currently has 14 FTAs in force (USITC 2014). It is beyond the scope of this article to detail the tariff treatment of fish products under each of these. Two examples are selected because of their actual or potential commercial relevance as suppliers of tuna products

\footnotetext{
${ }^{3}$ Data did not specify if pouches are included in the 'canned' category.
} 
representing a grouping of developing countries (Central America) and a member of the OECD (Korea). The Dominican Republic-Central America-United States Free Trade Agreement Implementation Act (CAFTA-DR) was signed in 2004. It entered into force for the United States, El Salvador, Guatemala, Honduras, and Nicaragua during 2006, for the Dominican Republic on 1 March 2007, and for Costa Rica on 1 January 2009 (USITC 2014). CAFTA-DR already provides duty free or extremely low duty for all processed tuna products entering the US market, subject to rules of origin. ${ }^{4}$ Several of these countries have a history of producing canned tuna and tuna loins, especially Costa Rica, El Salvador and Guatemala, which together have a combined annual production capacity of 78,000mt of raw material (Hamilton et al 2011a: 233). They also benefit from duty free access to the EU under the GSP+ (see above). There are however concerns around worker abuses in Dominican Republic, Guatemala and Honduras. The labour chapter and other clauses of the FTA are being used by the US in attempts to address these concerns (USITC 2014).

The United States-Korea Free Trade Agreement (KORUS) entered into force on 15 March 2012. For US tariff peaks on fish products, KORUS has one of the highest starting points of all of the US FTAs considered here (Table 1). This is likely to have been a defensive measure by the US government in KORUS negotiations to protect US tuna fishing and processing industry because Korean firms control a large fleet of tuna purse seiners (over 28 vessels) and long liners ( 150 vessels) and Dongwon Industries - the largest canning firm in Korea - owns the principal US canned tuna brand, Star-Kist. Canned tuna production in Korea is largely for domestic consumption (Hamilton et al. 2011a), but there are some exports to the US. This might be explained by the high tariff currently (in 2014) applied to canned tuna in oil (29\%) and in water (post-quota: $10.3 \%$ ), as detailed in Table 1. With the phase out of these tariffs by 2021, it is conceivable that Korea will export to the US; although Korea's relatively high cost structure - especially labour - may act as a competitive disadvantage.

\section{TARIFF REGIMES AND THE GEOGRAPHY OF CANNED TUNA PRODUCTION}

\footnotetext{
${ }^{4}$ Discrete rules of origin apply under different US preference regimes and FTAs. See Campling (2015b) for detail.
} 
The EU and US tariff regimes play a major role in shaping the structure of global tuna production. Tuna canneries in Africa, Latin America and the Pacific islands tend to focus on the EU market, largely as a direct result of tariff preferences, while those in Southeast Asia supply the US, Japan and the EU. Locations that focus only on canning and rely on imported loins are all in the global North, while specialised loining only takes place in the South, largely in small developing economies - representing a fragmentation of production that is in large part based around tariff policy. It should be noted that this aspect of the new international division of labour - the 'logic of loining' - is not solely about the search for cheap labour as popularly depicted, but also for ready access to tuna fisheries, more lax labour standards and environmental regulations, reduced transportation costs and access to existing ocean-going seafreight networks, ${ }^{5}$ and, importantly for this article, access to EU and US trade preferences.

The following provides a series of snap-shots of evidence of the effects of tariff protection and preferences on canned tuna production in the EU, the US, small vulnerable economies (SVEs), and countries trying to domesticate foreign industry. The cases are not uniform because the available evidence is not. Combined though, these vignettes serve to indicate the great diversity of trade relations in and development outcomes from tuna preference systems.

\subsection{EU tariff protection and canned tuna production}

Spain is the most important producer of canned tuna within the EU, accounting for $59 \%$ of production in 1998 and 68\% in 2007. It is also the world's second largest producer of canned tuna after Thailand, having apparently received a major boost from 1992 onwards with the institutionalisation of the EU Single Market (see Figure 1). Given highly competitive conditions in the Spanish market, this indicates the effectiveness of tariff protection combined with the various productivity-enhancing strategies of firms (Campling 2012a). Italy is the second largest producer in the EU (traditionally for domestic consumption) and is in decline, from 24\% of total EU production in 1998 to $19 \%$ in 2007 (Figure 1). Spain is now the leading supplier to the Italian market, not least because many Italian brands are controlled by Spanish

\footnotetext{
${ }^{5}$ Whole round tuna is traditionally transhipped using reefer carriers, but this class of vessels is aging. Transhipping loins in refrigerated containers thus means not only transporting a lower volume, higher value cargo, but also that the product can be inserted into global shipping networks. Some transhipment points such as Seychelles are now regularly stuffing refrigerated containers which allows the DWF to depend less on reefers and sell pre-sorted lots (by fish size and species).
} 
capital (Campling 2012a). Production in France has remained relatively stable, falling from $12 \%$ of the EU total in 1998 to $10 \%$ in $2007 .{ }^{6}$ Importantly, ready-made tuna salads constituted $70 \%$ of all domestic production of 'ambient' tuna products in France in 2002 (Catarci 2004: 23). ${ }^{7}$ This aspect neatly encapsulates the international division of labour in tuna processing: this product type is considerably more profitable because of the significantly reduced use of the highest cost raw material (the tuna itself), and is the main explanation for the survival of 'ambient' tuna production in France.

Figure 1: Canned tuna production in Spain, Italy and France, 1976-2007

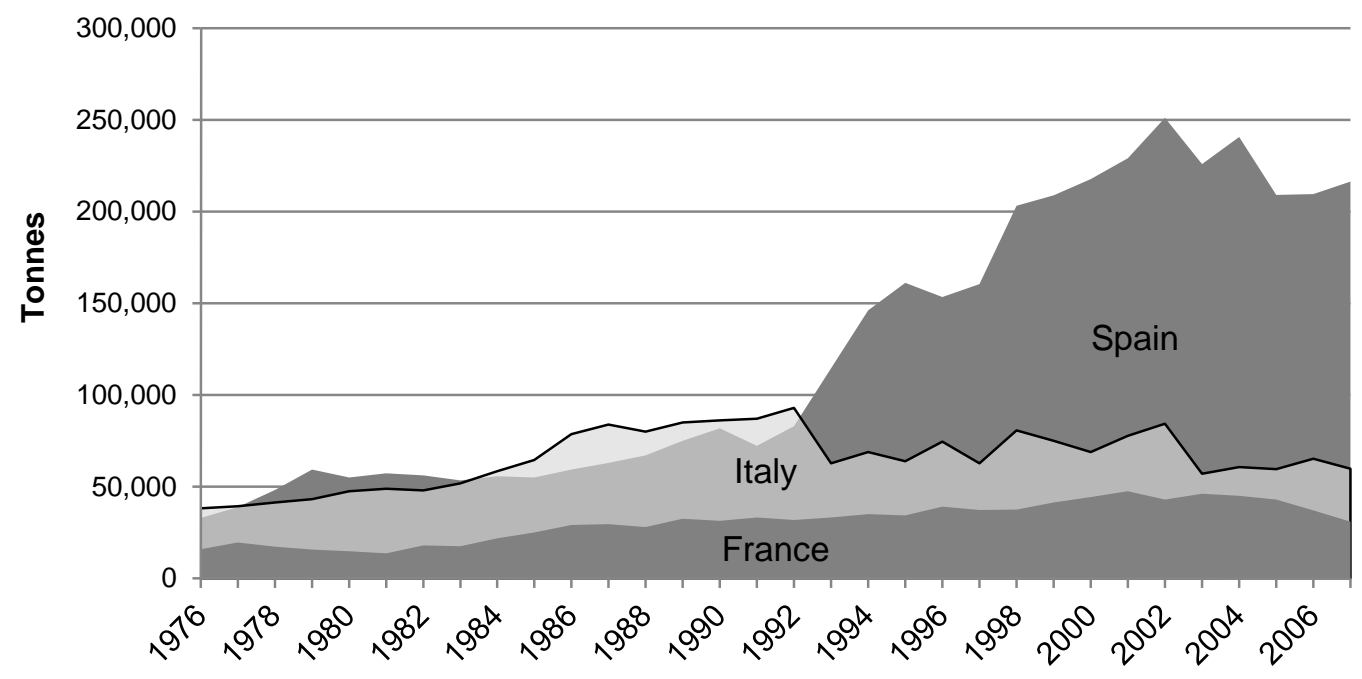

Note: EU production excludes Portugal

Sources: Campling 2012a (based on FAO Fishstat+ and Globefish 2010)

Export-orientated canned tuna production represents one of the few success stories of industrial 'upgrading' in the ACP under EU trade preferences. In aggregate terms, the ACP share of world production of canned tuna grew from 5\% to 12\% between 1976 and 2003 (Oceanic Développement et al. 2005), supporting the position that 'the Lomé Convention was in a key sense the midwife in the creation of the ... ACP canning industry' (Grynberg and White 1998: 68). Drawing upon their analysis of trade data to mid-Lomé IV, Davenport et al. found that fish was the most important non-oil ACP export to the EU and was 'one of the most

\footnotetext{
${ }^{6}$ Portugal is the fourth location of EU production. It had a 6\% share of the EU total in 1998, which fell to $4 \%$ in 2007.

${ }^{7}$ In the UK, 'ambient' product ('shelf-stable' in the US) refers to traditional canned products, as well as tuna in pouches and other so-called 'value-added' tuna products that can be kept in nonrefrigerated conditions for long periods of time (i.e. on the supermarket shelf).
} 
successful cases of processing in the ACP countries' (1995: 20; see also McQueen et al 1998). Total direct full-time equivalent employment in EU-centred tuna processing facilities in ACP island states and coastal regions in the mid-2000s (when EPA negotiations were in full swing) totalled over 15,000 workers: Côte d'Ivoire 3,000; Papua New Guinea 3,000; Mauritius 2,700; Senegal 2,400; Seychelles 2,300; Madagascar 1,300; Solomon Islands 1,000; Ghana 2,000; Kenya 800 (Campling 2008). The indirect and induced employment produced by the activity of the factories is considerable. This is not to claim that the preference was the sole determinant in this process, but that it was an integral aspect of a set of necessary conditions (Havice and Campling 2013).

The GSP+ regime had important effects on industrial tuna production in Latin America in particular. Between 1976 and 2003, the share of GSP Plus countries of world production of canned tuna grew from 3\% to 9\% (Oceanic Développement 2005). The GSP+ (and the 'Drugs Agreement' before it, see Campling et al. 2007) provided the trigger for large-scale investment by Spanish processing firms, investing hundreds of millions of Euros in Ecuador, El Salvador, Guatemala and Venezuela. EUROTHON (the EU Tuna lobby group) estimates that its members have created 35,000 jobs in fishing and processing industries in Latin America (due principally to the incentive of the GSP) (EUROTHON 2006).

\subsection{US tariff escalation and the 'logic of loining'}

The US had the first and, for a long time, the largest tuna canning industry. It has always been protected by high tariff peaks. As competition emerged first from Japan and later from Thailand, other Southeast Asian Countries and Latin America, the US industry switched production to the US Territories of American Samoa and Puerto Rico before making investments in Latin America and Southeast Asia. In 2001, Thailand overtook the US as the largest producer of canned tuna, and soon after Spain pushed the US to third place. It has been in relative decline ever since.

The two canneries in mainland USA use only tuna loins in the production process and do not process any whole round fish. Importing loins not only outsources the labour-intensive process of cleaning fish to lower cost production sites, unlike the EU where loins are met with a $24 \%$ MFN tariff, loins can be imported to the US market at only $6 \%$ (Table 1 ). This means that loins can be sourced from multiple locations without concern about $\mathrm{RoO}$ or the need for tariff quotas. As a result, US-based processors can take advantage of diversified supply 
strategies - a 'global ocean strategy' (Table 4) - that involve a combination of supply contracts, long-term management contracts and even direct financial investments in processing facilities around the world.

Table 4: Yearly imports of tuna loins into USA, in $1,000 \mathrm{mt}$

\begin{tabular}{lllll}
\hline & $\mathbf{2 0 1 0}$ & $\mathbf{2 0 1 1}$ & $\mathbf{2 0 1 2}$ & $\mathbf{2 0 1 3}$ \\
\hline Thailand & 26.8 & 24.7 & 20.1 & 22.1 \\
China & 0.0 & 6.2 & 11.0 & 14.3 \\
Fiji & 14.9 & 4.6 & 10.3 & 11.6 \\
Colombia & 5.0 & 6.9 & 13.9 & 9.5 \\
Mauritius & 4.9 & 8.6 & 5.8 & 7.5 \\
Ecuador & 0.1 & 0.9 & 2.7 & 0.7 \\
Others & 13.1 & 9.6 & 2.5 & 4.1 \\
Total & 64.8 & 61.5 & 66.3 & 69.8 \\
\hline
\end{tabular}

Source: Globefish 2014

\subsection{Small vulnerable economies and preference dependence}

It is widely recognised that small vulnerable economies (SVEs) suffer from competitive disadvantages associated with their scale and geographical isolation (WTO 2015; Campling 2006). US, and especially, EU tariff preferences have been instrumental to the development and survival of tuna processing facilities in SVEs in the Indian and Pacific oceans. Several ACP states engaged in the negotiation of reciprocal EPAs largely to maintain, previously nonreciprocal, preferential market access for a range of products, including for processed fish (e.g. processed hake from Namibia, Nile Perch fillets from east Africa). For example, continuing duty-free market access for canned tuna was a central reason for entering into an Interim EPA for Papua New Guinea and Seychelles, and as a component alongside other preferential items for Fiji, Ghana, Ivory Coast, Madagascar and Mauritius (Campling 2015a). However, despite some similarities as SVEs, national experiences are highly differentiated.

Countries like Mauritius and Seychelles are success stories of the EU canned tuna preference. They specialize in processing EU-caught fish and both signed an IEPA in 2007 
with the EU to maintain Lomé/ Cotonou preferences. Mauritius largely produces canned tuna and tuna loins for the EU, but it also export loins to the US under the AGOA preference scheme (Table 4). In 2007, the Mauritius Seafood Hub probably contributed between 2 and 3 per cent of GDP and generates 15,000 direct full time equivalent jobs (Barnes and Campling 2008). The tuna cannery in Seychelles is dependent on preferential access to the EU market, is the largest private sector employer and accounts for over $90 \%$ in value of all goods exports (Campling 2012a). Under IEPA RoO, both countries are locked into processing EU-caught fish, which can result in supply problems during the down season in the Western Indian Ocean fishery. Although, in their IEPA they negotiated an automatic derogation for canned tuna $(8,000 \mathrm{mt})$ and tuna loins $(2,000 \mathrm{mt})$ that provides some supply flexibility (Campling 2008b). This suggests that negotiating more flexible $\mathrm{RoO}$ (or derogations from $\mathrm{RoO}$ ) is a useful adjustment mechanism for the ACP to deal with falling preference margins. Given the growing impact of FTAs on preferences, more flexible RoO in that context could help smaller producers enter value chains with better access to their old markets.

In contrast, Fiji and the Solomon Islands both found in the late 1990s that they could no longer compete in EU markets for canned tuna even with the Lomé preference and downgraded to solely processing loins: Fiji to the US market using foreign caught fish, and the Solomon Islands to the EU under the EBA using fish caught by its own fleet, albeit with supply problems due to seasonality and exports loins to the US to keep the factory moving (Barclay 2010; Campling 2012a; Havice et al. 2014). Both are seen as crucial sources of employment in otherwise isolated regions within these two countries, especially for women (Lambeth et al. 2004).

In the cases of Fiji and Mauritius, the ongoing supply of loins to the US market (which does not apply a tariff of major significance on tuna loins) suggests that there is a degree of cost competitiveness to labour intensive processing in these two SVEs (Table 4). However, given that US tariff escalation on canned tuna in effect creates the market for pre-cooked frozen loins, the market for loins will exist only as long EU, Japan and US trade policy continues to protect their domestic canning sectors.

An important weakness of GSP schemes from the perspective of beneficiary countries is that they can be unilaterally reformed or rescinded. A good example of the risks associated with reliance on unilateral preferences is Maldives. A major beneficiary of the EBA, duty free access to the EU market supported two canned tuna factories supplied by a huge local smallscale fleet. However, Maldives graduated from LDC status in 2011 and was removed from the EBA in 2014. Without this preference its exports appear to be less competitive, evidenced in a 
$40 \%$ drop in exports over the first half of 2014 compared to the same period in 2013. Instead, Maldives is exporting more of its MSC-certified fish to Thailand for export-orientated processing to the EU (Atuna 2014a). According to the logic of the pro-liberalisers (section 1.1), this is the most efficient outcome as comparative costs are minimised. However, given that tuna processing is a large employer of low-skilled labour and the Maldivian economy is yet to substantially diversify beyond tourism, it is unclear where the next round of jobs will come from. It is plausible that the Maldives will emerge as a supplier of specialised intermediate goods (e.g. whole tuna or loins certified by MSC) to producers with competitive scale economies in processing such as Thailand.

\subsection{Preference dependence and domestification}

Larger coastal states have tried to leverage the combination of market access opportunities presented by tariff preferences and access to rich fisheries in their EEZs to encourage local and/or foreign investment in onshore tuna processing. Ecuador is the world's second largest export orientated tuna processor and a major example of preference-related fisheries development, much of which is domestically owned (Hamilton et al. 2011a; Globefish 2014). It is dependent on both EU and US trade preferences, particularly the GSP+, with the EU accounting for around 60\% of Ecuador's total tuna exports (Atuna 2014b; Tables 2 above). Tuna exports to the US consist almost entirely of pouches (with an MFN tariff of $12.5 \%$ ), which were duty free under the Andean Trade and Development Preferences Act (ATDPA). Ecuador has a large domestic fishing fleet that meets both EU and US rules of origin. However, Ecuador graduates from GSP+ status in 2015 because the country's gross income took it out of the EU's reformed 'vulnerability' criteria. To counter the threat to export competitiveness, Ecuador signed a Free Trade and Development Agreement with the EU in July 2014, which provides preferential access for fisheries products, including tuna and shrimp (McCoy et al. 2014a). Similarly, the ATDPA expired at the end of 2012. Pouch exports only remained at prior levels because the Ecuadorian government provided domestic industry with a temporary subsidy payment (over two years) that offsets the cost of the duty (Havice et al. 2014). This subsidy offers another example of how a country adapted to the loss of trade preferences. Whether or not it is an option that is sustainable is an empirical question (e.g. the direct subsidy to maintain employment may or may not be preferable to the provision of social welfare 
payments), but it certainly suggests a temporary adjustment measure that could be recognised by the multilateral trade system.

In more recent years, others have tried to follow the strategy of fisheries domestification, most prominently Papua New Guinea. Due to a combination of geographical isolation and other costs of doing business, processed tuna exports from PNG are dependent upon duty free access to the EU market. In addition to the EU preference, a major explanation for onshore processing investment in PNG is 'second generation' fisheries access: by committing to onshore investment, foreign firms are allocated considerably more fishing licenses than necessary to supply that plant, offering long-term strategic resource access (Hamilton et al. 2011b). Nonetheless, the tuna industry provided about $1.2 \%$ of all formal monetary jobs in PNG in 2008 (Gillett 2009), with a disproportionate impact on women, with around $3.3 \%$ of all formally employed women working in onshore tuna processing jobs (Sullivan and Ram-Bidesi 2008), which together with net purchases in local businesses generates considerable net income to the economy (Hamilton et al. 2011b). A major constraint on deepening this development process was EU RoO which meant that there was 'insufficient wholly-obtained fish to meet on-land demand [given] the very limited fishing capacity of the Pacific States' fishing fleet' (PACP-EU IEPA, Protocol II, Article 6.6(a)). As such, the negotiation of 'global sourcing' $\mathrm{RoO}^{8}$ in the Pacific ACP IEPA provided a necessary component for increased investment in onshore processing capacity, ostensibly to export fish products to the EU. A study commissioned by the European Parliament (2012) estimates that new investment stemming from the reformed RoO will see PNG's local benefits from tuna processing grow from US $\$ 21 \mathrm{~m}$ in 2012 to $\$ 70 \mathrm{~m}$ by 2018 and employment increase to 20,000 . As noted earlier, reform of RoO could be seen as a very important adjustment measure to help countries retain some competitiveness as preferences fall.

\section{CONCLUSION}

The majority of commercial capture fisheries species are at or beyond their sustainable limits. There should be no confusion about the positive linkages between good fisheries management and environmental effects. Therefore, given the current lack of evidence on the effects of trade

\footnotetext{
${ }^{8}$ This rule permits signatories to source tuna from any vessel regardless of flag or where it was caught, provided it has been 'substantially transformed' by a Pacific ACP-based processing facility. In technical RoO terms this is a change in tariff classification method.
} 
liberalisation on fisheries, a first principle in fisheries trade policy must be the precautionary approach. Using the case of canned tuna, this article argued that tariff regimes are about capturing a relative share of the already fragile pie by influencing the location of production by raising or reducing costs vis-à-vis competitors, they are not about expanding the pie to new limits. This report has argued that the development impact of trade preferences cannot be understood outside of the particular characteristics of the beneficiary country. Environmental change, local state policy (e.g. around resource access), distant water fleets, multinational firms and other investors, organized labour, civil society/ NGOs, and donors can all play a role in shaping the development possibilities associated with commercially viable trade preferences. This makes general recommendations difficult. One thing is clear: the need for sensitivity to complexity and contingency in understanding the dynamics of change. This certainly suggests that one-size-fits-all policy prescriptions based on simplistic assumptions of the functioning of the world economy will not alone suffice as a policy framework. At a minimum, there needs to be more attention to careful differentiation among countries, recognising that 'trade and development policy may not be coherent for all developing countries concerned' (OECD 2006a: 52). Disaggregation and context are necessary for evidence-based policy making to take account of species- and country-specific dynamics.

More research is needed on the existing relationship between fish trade liberalisation, industrial policy and job creation, poverty reduction and food security, in contradistinction to policy prescriptions based on highly aggregated data and idealised assumptions either of perfectly functioning markets or of the ability of states to 'direct' economic outcomes with trade and industrial policy. To understand the effects of tariff escalation and preferences and their actual and potential liberalisation, a variety of research methods and sources of evidence are required. At a minimum this would require combining quantitative analysis of the longitudinal relationship between fish production and trade and a range of policy mechanisms (e.g. tariffs, regulations, government investment incentives), with the careful comparative qualitative study of value chains in strategically selected case studies of particular fish products and local social relations and contexts.

\section{Acknowledgements}

I have worked as a trade and industry analyst for the Pacific Islands Forum Fisheries Agency since December 2007. My views do not necessarily reflect those of FFA, but I am thankful to all of those that I have worked with at FFA and collaborators on FFA projects for their sharing of knowledge and 
insights. I also acknowledge participants at the second workshop of the E15 Expert Group on Oceans, Fisheries and the Trade System where an earlier version of this paper was presented and a wide range of insightful comments and criticisms were made. My final thanks are to the peer reviewers for very helpful suggestions. All errors remain my own.

\section{REFERENCES}

Ahmed, Mahfuz (2006), Market Access and Trade Liberalisation in Fisheries, ICTSD Natural Resources, International Trade and Sustainable Development Series Issue paper No. 4. Geneva: ICTSD.

Allain, Marc (2007), Trading Away Our Oceans: Why trade liberalization of Fisheries must be abandoned, Amsterdam: Greenpeace International

Asche, F. and M.D. Smith (2010), 'Trade and fisheries: key issues for the World Trade Organization', WTO Staff Working Paper ERSD-2010-03.

Atuna (2014a), 'Will Maldives Canners Survive The EU Tariff Rise?', 8 September 2014.

Atuna (2014b), 'How dependent are Ecuador's exports on Europe?', 14 July.

Barclay, Kate (2010), 'Impacts of tuna industries on coastal communities in Pacific Island countries', Marine Policy, 34: 406-413

Barnes, C. and Campling, L. (2008). The Competitive Position of the Mauritius Seafood Hub, Present and Future Challenges, Development Options and Scenarios. Report to the Mauritius Board of Investment and Commonwealth Secretariat.

Bartels, Lorand, Louise de la Fayette, Helen Davies and Liam Campling (2007). Policy Coherence for Development and the Effects of EU Fisheries Policies on Development in West Africa, Brussels: European Parliament.

Béné, C., R. Lawton and E. H. Allison (2010), “"Trade Matters in the Fight Against Poverty”: Narratives, Perceptions, and (Lack of) Evidence in the Case of Fish Trade in Africa', World Development, 38 (7): 933-954.

Béné, C., R. Arthur, H. Norbury, E.H Allison, M. Beveridge, S. Bush, L. Campling, W. Leschen, D. Little, D. Squires, S. H. Thilsted, M. Troell and M. Williams 2016, 'Contribution of Fisheries and Aquaculture to Food Security and Poverty Reduction: Assessing the Current Evidence', World Development, 79 (early view).

Bostock, T., G. Greenalgh and U. Kleith (2004), Policy Research - Implications of liberalisation of fish trade for developing countries, Chatham: Natural Research Institute.

Brander J.A. and M.S. Taylor (1997), 'International trade and open-access renewable resources: the small open economy case', The Canadian Journal of Economics 30(3): 526552 
Bush, S. R. \& P. Oosterveer (2007), 'The missing link: intersecting governance and trade in the space of place and the space of flows', Sociologia Ruralis 47(4): 384-400.

Campling, L. (2006) 'A Critical Political Economy of the Small Island Developing States Concept: South-South Cooperation for Island Citizens', Journal of Developing Societies, 22(3): 235-285

Campling, L. (2008a), 'Direct and Indirect Preference Erosion and the Competitiveness of the ACP Tuna Processing Sector', in V. Qalo (ed.), Bilateralism and Development: Emerging Trade Patterns. London, Cameroon May.

Campling, L. (2008b) Fisheries Aspects of ACP-EU Interim Economic Partnership Agreements: Trade and Sustainable Development Implications. ICTSD Series on Fisheries, Trade and Sustainable Development - Issue Paper No. 6. Geneva: International Centre for Trade and Sustainable Development.

Campling, L. (2012a). The EU-centred Commodity Chain in Canned Tuna and Upgrading in Seychelles. PhD thesis, School of Oriental and African Studies, University of London.

Campling, L. (2012b). 'The tuna 'commodity frontier': business strategies and environment in the industrial tuna fisheries of the Western Indian Ocean'. Journal of Agrarian Change, 12 (2-3), 252-278

Campling, L. (2015a). 'Historicising trade preferences and development: The case of the ACPEU canned tuna preference'. In G. Fridell and K. Ervine, Beyond Free Trade, Basingstoke: Palgrave.

Campling, L. (2015a). Tariff Escalation and Preferences in International Fish Production and Trade. E15 Expert Group on Oceans, Fisheries and the Trade System. Geneva: International Centre for Trade and Sustainable Development and World Economic Forum

Campling, L. and E. Havice (2007), 'Industrial development in an island economy: US trade policy and canned tuna production in American Samoa', Island Studies Journal, 2(2): 209228.

Campling, L. and E. Havice (2014a), 'New report summarises impacts of American Samoa minimum wage increases as Tri Marine investment moves forward', FFA Trade and Industry News, 7(2): March-April.

Campling, L. and E. Havice (2014b), 'EU Loins Quota for 2014 exhausted in ten days', FFA Trade and Industry News, 7(1): January-February.

Campling, L. and E. Havice (2014c), 'The problem of property in industrial fisheries', Journal of Peasant Studies, 41 (5): 707-727

Campling, L., E. Havice and P. McCall Howard (2012), 'The Political Economy and Ecology of Capture Fisheries: Market Dynamics, Resource Access and Relations of Exploitation and Resistance', Journal of Agrarian Change, 12 (2-3): 177-203 
Campling, L., E. Havice and V. Ram-Bidesi (2007), Pacific Island Countries, the Global Tuna Industry and the International Trade Regime, Honaira: Pacific Islands Forum Fisheries Agency.

Catarchi, Camillo (2004), 'World Tuna Markets', GLOBEFISH Research Programme, Vol. 74, Rome: FAO

CBP 2013, Side-by-Side Comparison of Free Trade Agreements and Selected Preferential Trade Legislation Programs--Non-Textiles, November 19, 2011. US Customs and Border Protection, Department of Homeland Security.

Chang, H-J. (2004), Kicking Away the Ladder: Development Strategy in Historical Perspective, London, Anthem Press

Clark, Les (2006). Perspectives on Fisheries Access Agreements: Developing Country Views', in OECD, Fishing for Coherence: Proceedings of the Workshop on Policy Coherence for Development in Fisheries, Paris: OECD

Commere, Pierre (2009), 'Overview of the European tuna market', Paper presented to the 2nd European Tuna Conference, Brussels 27 April 2009

Commission for Africa (2005), Our Common Interest: Report of the Commission for Africa, London: Commission for Africa.

Davenport, M. (1992). Africa and the Unimportance of Being Preferred. Journal of Common Market Studies, XXX (7), 233-251

Davenport, M., Hewitt, A., and Koning, A., (1995). Europe's Preferred Partners? The Lomé Countries in World Trade. London: Overseas Development Institute

DG TRADE and DG DEV (2002), Economic Partnership Agreements - Start of Negotiations: A new approach in the relations between the European Union and the ACP countries. Brussels: Directorate-General for Trade and Directorate-General for Development, European Commission.

Duncan, Ron (2006). 'Troubled Fishing in Pacific Waters'. Pacific Economic Bulletin 21 (3): 98-105

Estudios Biologicos (2006), Chapter 6 'Evaluación de los costes de explotación de un buque atunero' (circulated and translated by Béatrice Gorez)

European Parliament (2012), 'Application of the System of Derogation to the Rules of Origin of Fisheries Products in Papua New Guinea and Fiji', requested by the Committee on Fisheries, Brussels.

EUROTHON (2006), 'EUROTHON Position on the WTO Negotiations Regarding the Tariff Preference Erosion in the Tuna Market', May 
FAO (2014), The State of World Fisheries and Aquaculture: Opportunities and challenges, Rome: FAO

Felando, August and Harold Medina (2012), 'The Origins of California's High-Seas Tuna Fleet', The Journal of San Diego History, 28 (1-2): 1-40

FITAG-ANFACO (2011), Joint Statement of Defence of the Community Prepared and Canned fish and Shellfish Industry Against EU Trade Agreements with Third Countries. Submitted by Juan M. Vieites Baptista de Sousa, Secretart General, ANFACO-CECOPESCA, to Joachim Zeller, DG Trade, European Commission, 1 August 2011.

Gillett, R. (2009). Fisheries in the economies of the Pacific Island Countries and Territories. Mandaluyong City, Philippines: Asian Development Bank

Gillett, Robert and Garry Preston (2012), 'Feasibility Assessment of Exporting Products of HS Headings 0304/ 0305 to the European Union'. Report Prepared for the Pacific Islands Forum Secretariat (February).

Globefish (2014). Commodity Update: Tuna. Food and Agriculture Organization: Rome.

Grynberg, R. and M. White (1998), 'EU Tuna Preferecnes in the Post-Lomé Environment', in R. Grynberg (ed.), The Lomé Convention and the Pacific, Suva: Forum Secretariat and University of the South Pacific

Grilli, E.R., (1993). The European Community and the Developing Countries. Cambridge: Cambridge University Press.

Guillotreau, P. and N. Péridy (2000), 'Trade barriers and European imports of seafood products: a quantitative assessment', Marine Policy, 24 (5): 431-437

Hamilton, A., A. Lewis, M.A. McCoy, E. Havice, and L. Campling (2011a), Market and Industry Dynamics in the Global Tuna Supply Chain. Honiara: Pacific Islands Forum Fisheries Agency

Hamilton, A., T. Lewis and L. Campling (2011b), 'Report on the implementation of the derogation to the standard rules of origin granted to the Pacific ACP States in the framework of the Interim Economic Partnership Agreement', report commissioned by European Commission, FWC COM 2011 RFS 2011/266449.

Havice, E. and L. Campling (2013), 'Articulating upgrading: Island developing states and canned tuna production', Environment and Planning A, 45(11), 2610-2627

Havice, E., L. Campling, M. McCoy and T. Lewis (2014), 'Pacific Island Countries and United States of America Development-Oriented Trade \& Investment Study - Fisheries Component', Suva: Pacific Islands Forum Secretariat. 
Heydon, K. (2006), 'Trade and Fisheries Globalisation: Issues for Developing and Developed Countries', in OECD (ed.), Fishing for Coherence: Proceedings of the Workshop on Policy Coherence for Development in Fisheries, Paris: OECD

ICTSD (2006), Fisheries, International Trade and Sustainable Development: Policy Discussion Paper, ICTSD Natural Resources, International Trade and Sustainable Development Series. Geneva: ICTSD

Jones, Vivian C. (2014), 'Generalized System of Preferences: Background and Renewal Debate', CRS Report for Congress, Congressional Research Service.

Kurien, J. (2005), 'Responsible fish trade and food security', FAO Fisheries Technical Paper 456, Rome: FAO

Lambeth, Lyn, Margaret Leniston and Aliti Vunisa (2004), Gender issues in the tuna industry: Pacific Examples - Volume 2, Suva: Pacific Islands Forum Secretariat

Manchin, Miriam (2006), 'Preference Utilisation and Tariff Reduction in EU Imports from ACP Countries', The World Economy, 29(9): 1243-1266.

Martini, R. and C. Lindberg (2013), 'Fishing for Tomorrow: Managing fisheries for sustainable development', Coherence for Development, 2 (December), Paris: OECD

Mwikya, S.M. (2006), 'Trade issues and policy coherence in fisheries: A developing country perspective', in OECD (ed.), Fishing for Coherence: Proceedings of the Workshop on Policy Coherence for Development in Fisheries, Paris: OECD

McCoy, M., E. Havice and L. Campling (2014a), 'Ecuador concludes a Free Trade Agreement with the EU', FFA Trade and Industry News, 7(4): July-August.

Melchior, A. (2006), 'Tariffs in World Seafood Trade', FAO Fisheries Circular no. 1016, Rome: FAO.

Milberg, W. and D. Winkler (2013). Outsourcing Economics: Global Value Chains in Capitalist Development, Cambridge University Press.

Naumann, E. (2010), Rules of Origin in EU-ACP Economic Partnership Agreements, Geneva: International Centre for Trade and Sustainable Development

Nieto, G. E. (2006), 'Chapter 4: Policy coherence: Trade and developing countries', in OECD (ed.), Fishing for Coherence: Proceedings of the Workshop on Policy Coherence for Development in Fisheries, Paris: OECD

NMFS 2014, Fisheries of the United States, 2013, National Marine Fisheries Service.

NOAA Fisheries 2012, 'Current fishery statistics No. 2011-2; Imports and Exports of Fishery Products Annual Summary, 2011'. National Marine Fisheries Service.NOAA Fisheries 
2014, 'Current fishery statistics No. 2013-2; Imports and Exports of Fishery Products Annual Summary, 2013'. National Marine Fisheries Service.

Oceanic Développement, Poseidon and Megapesca (2005), The European Tuna Sector: Economic Situation, Prospects and Analysis of the Impact of the Liberalisation of Trade, Specific Convention SC 12, Project Fish/ 2003/02, Final Report

OECD (2003), Liberalising Fisheries Markets: Scope and Effects, Paris: OECD

OECD (2006a), Fishing for Coherence: Fisheries and Development Policies, Paris: OECD

OECD (2006b), Fishing for Coherence: Proceedings of the Workshop on Policy Coherence for Development in Fisheries, Paris: OECD

OECD (2012), Globalisation in Fisheries and Aquaculture: Opportunities and Challenges, Paris: OECD

Paredes, Pilar (2006), 'Tariffs, Preferential Tariff Arrangements and Tariff Escalation: Policy Coherence Issues', in OECD (ed.), Fishing for Coherence: Proceedings of the Workshop on Policy Coherence for Development in Fisheries, Paris: OECD

Petersen, Elizabeth (2006), Institutional Economics and Fisheries Management: The Case of Pacific Tuna. Cheltenham, UK: Edward Elgar.

Ponte, S., J. Raakjær and L. Campling (2007). Swimming Upstream: Market Access for African Fish Exports in the Context of WTO and EU Negotiations and Regulation. Development Policy Review, 25(1): 113-138.

Ravenhill, J., (1985), Collective Clientalism: The Lomé Conventions and North-South Relations. New York: Columbia University Press

Roheim, Cathy (2004), Trade Liberalization in Fish Products: Impacts on Sustainability of International Markets and Fish Resources, Washington DC: World Bank.

Schmidt, Carl-Christian (2003), 'Globalisation, Industry Structure, Market Power and Impact on Trade Opportunities and Challenges for Developed (OECD) Countries'. Paper prepared for the FAO Industry and Expert Consultation on International Trade, Rio de Janeiro, Brazil, 3-5 December 2003.

UNCTAD (2010), Generalized System of Preferences: Handbook on the Scheme of the United States of America, New York and Geneva: UNCTAD.

UNEP (2002a), Integrated Assessment of Trade Liberalization and Trade-related Polices: A country study on the Argentina fisheries sector, New York and Geneva: United Nations Environment Program 
UNEP (2002b), Integrated Assessment of Trade Liberalization and Trade-related Polices: A country study on the fisheries sector in Senegal, New York and Geneva: United Nations Environment Program

USITC (2014), The Harmonized Tariff Schedule of the United States, Annotated for Statistical Reporting Purposes, USITC Publication 4446, Washington, DC: United States International Trade Commission

USTR (2009), 'U.S. Generalized System of Preferences (GSP) Guidebook', Washington DC: Office of the United States Trade Representative.

USTR (2012), 'GSP-eligible products for Least Developed Beneficiary Countries', Washington DC: Office of the United States Trade Representative.

USTR (2014), Trade Policy Agenda and 2013 Annual Report, Washington DC: Office of the United States Trade Representative.

Wade, R. (1990), Governing the Market: Economic Theory and the Role of Government in East Asian Industrialization, Princeton, New Jersey: Princeton University Press

Winters, L. A. and P. M. G. Martins (2004). When Comparative Advantage is not Enough: Business Costs in Small Remote Economies. World Trade Review, 3(3): 347-383.

WTO (1997). Environmental Benefits of Removing Trade Restrictions and Distortions (Note by the Secretariat). WT/CTE/W/67. Geneva: World Trade Organisation

WTO (2015), 'Work programme on small economies'. Available at: https://www.wto.org/english/tratop_e/devel_e/dev_wkprog_smalleco_e.htm (last accessed 18 September 2015) 